\title{
Middle Miocene serial killers: drilled gastropods from the south-western margin of the Central Paratethys, Croatia
}

\author{
Marija Bošnjak, ${ }^{1}$ Jasenka Sremac, ${ }^{2}$ Bojan Karaica, ${ }^{3}$ Ivan Mađerić, ${ }^{4}$ and Anja Jarić ${ }^{5}$ \\ ${ }^{1}$ Croatian Natural History Museum, Demetrova 1, 10000 Zagreb, Croatia; (marija.bosnjak@hpm.hr) \\ 2 University of Zagreb, Faculty of Science, Department of Geology, Horvatovac 102a, 10000 Zagreb, Croatia \\ 3 The Ministry of Economy and Sustainable Development, Radnička cesta 80, 10000 Zagreb, Croatia \\ ${ }^{4}$ Prudic 22, 10291 Zdenci Brdovečki, Croatia \\ 5 Tratinska 57, 10000 Zagreb, Croatia
}

doi: $10.4154 / g c .2021 .19$

\begin{abstract}
This paper focuses on traces of drilling predation in the middle Miocene gastropod assemblage of the Zaprešić Brijeg locality, Croatia, which provides further insight into the palaeoecology of the south-western margin of the Pannonian Basin System during the Badenian. The analyzed gastropod shells were collected in the first half of the 20th century, and are housed in the Croatian Natural History Museum (CNHM) in Zagreb. The CNHM Zaprešić Brijeg collections contain 11063 gastropod shells, of which 1024 have been identified as drilled ( $9.3 \%$ of the sample), with 633 successfully drilled, 113 unsuccessfully drilled, and 278 multiply drilled shells. The most represented families are Potamididae, Nassariidae, Clavatulidae, Turritellidae, Cerithiidae, Muricidae and Naticidae. The gastropod families Naticidae and Muricidae are recognized as the probable predators based on the shape of the drill holes. Middle Miocene (Badenian) gastropods drilling frequency at Zaprešić Brijeg is $5.72 \%$, which is lower than the recorded Badenian gastropods drilling frequency in the Central Paratethys, while the overall gastropod prey effectiveness from the studied locality $(15.15 \%)$ is higher than the average of the neighbouring Badenian localities in the Central Paratethys. Among the most represented gastropods at this locality, the highest drilling frequency occurs in the infaunal suspension feeders Turritellidae (14.45\%), which mostly show traces of the naticid drilling.
\end{abstract}

Article history:

Manuscript received December 17, 2020 Revised manuscript accepted August 25, 2021 Available online October 20, 2021

Keywords: Drilling predation, Naticidae,

\section{INTRODUCTION}

Drilling predation is one of the most studied biotic interactions in the fossil record, and papers dealing with this topic have been extensively published since the 1960s (see KLOMPMAKER et al., 2019 and references therein). Information retrieved from the fossil traces, in this case preserved as drill holes, provide insight into the predator-prey relationship and other aspects of palaeoecology. According to KLOMPMAKER et al. (2019, Fig. 2), the majority of the research papers on drilling predation refer to molluscs; the majority of predation evidence occurs as a drill hole, with predominantly molluscs being both prey and predator. Fossil and extant gastropod families recorded as predators include the Capulidae (parasitic), Cassidae, Eulimidae (parasitic), Marginellidae, Muricidae, Nassariidae and Naticidae (e.g., CARRIKER, 1981; KABAT, 1990; ZŁOTNIK, 2001; KLOMPMAKER et al., 2019 and references therein). The most studied shell drilling predators among them are the naticids and muricids.

While there are many papers dealing with predatory drillings on recent mollusc (bivalves and gastropods) shells, only a few of them document such behaviour in the middle Miocene (Badenian) of the Central Paratethys (e.g., HOFFMANN et al., 1974; GÖRÖG \& SOMODY, 1988; KOWALEWSKI, 1990; HOFFMEISTER \& KOWALEWSKI, 2001; ZŁOTNIK, 2001; SAWYER \& ZUSCHIN, 2011; GANIĆ et al., 2016). In the aforementioned predation studies on the middle Miocene molluscs from Central Paratethys, there are no data from Croatia. Here, we report for the first time drilling analysis on the middle Miocene gastropods from Croatia, on the south-western margin of the Central Paratethys.
The Croatian Natural History Museum (CNHM) in Zagreb hosts a large collection of the middle Miocene (Badenian) marine gastropods from the Zaprešić Brijeg locality near Samobor, 30 $\mathrm{km}$ west of Zagreb, Croatia (Fig. 1), where many of the shells have predation marks in the form of drill holes. The Zaprešić Brijeg fossils (gastropods and bivalves) were originally collected at the beginning of the 20th century from the highly fossiliferous , light yellow sandstones" outcropping in local vineyards of Zaprešić Brijeg (also known as Zaprešić Breg, Zaprešićki Vinogradi or Vrhovčak). Bulk sampling was organized by the curator of the Samobor Museum, Stjepan Orešković, and performed by the local residents (e.g., PAVLOVSKY, 1957). The collection was later housed in the CNHM.

Our objective was to count drilling frequencies in the Zaprešić Brijeg material, and to compare them to the available data from the middle Miocene (Badenian) of the Central Paratethys (e.g., GÖRÖG \& SOMODY, 1988; HOFFMEISTER \& KOWALEWSKI, 2001; SAWYER \& ZUSCHIN, 2011; GANIĆ et al., 2016) (Fig. 2). In this study the focus is on: (1) the frequencies of the drill holes present on the gastropods; and (2) their probable predator(s).

\section{GEOLOGICAL SETTING}

The Zaprešić Brijeg locality lies west of the centre of Samobor, and $2 \mathrm{~km}$ south-east of the village of Dubrava, towards the village of Vrhovčak, around $30 \mathrm{~km}$ from Zagreb (Fig. 1).

This area is part of the rift-type North Croatian Basin (NCB), located in the south-western part of the Pannonian Basin System (PBS) surrounded by the Alps, Carpathians and Dinarides (e.g., PAVELIĆ \& KOVAČIĆ, 2018) (Fig. 2). Palaeogeographically it 


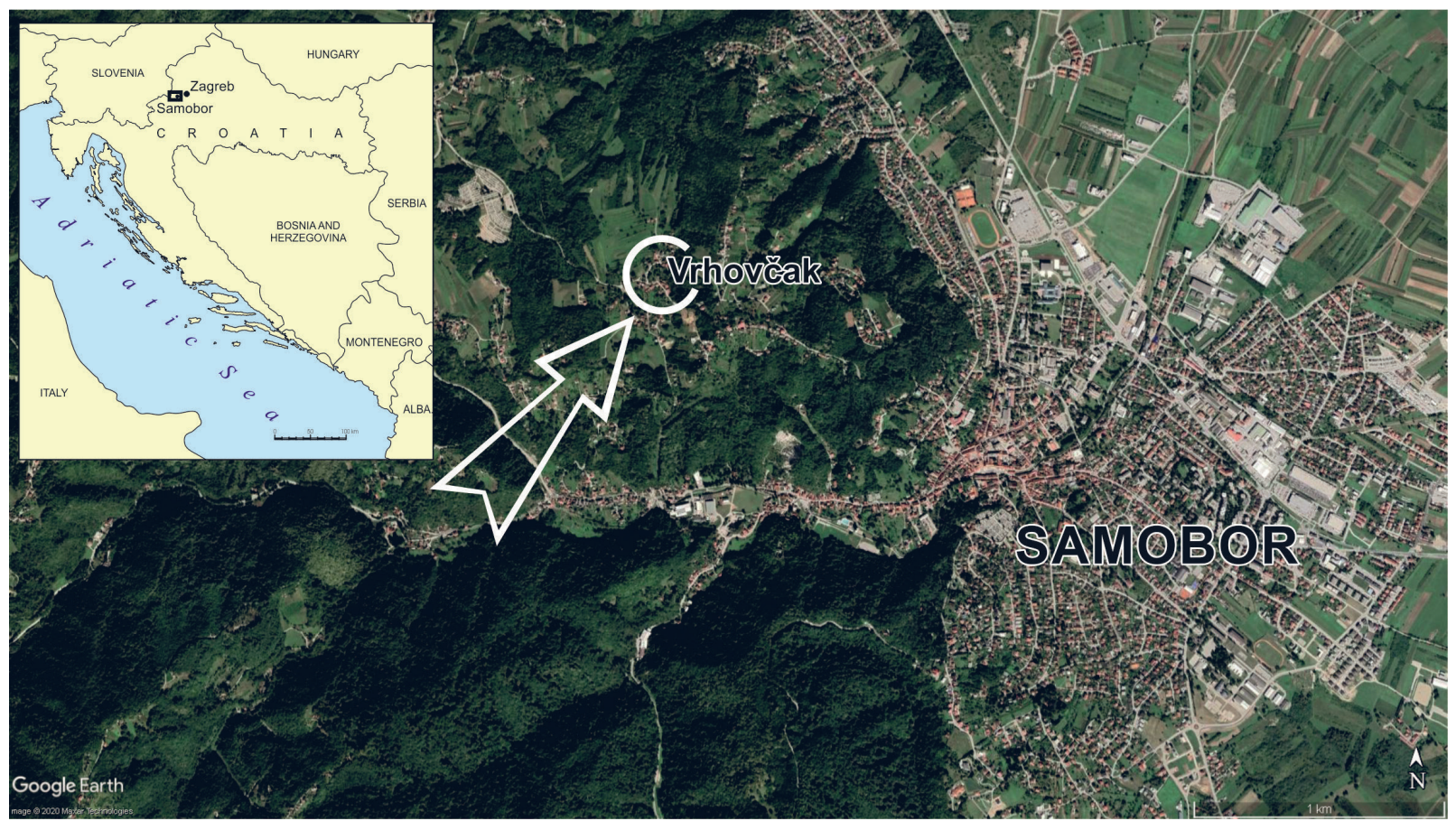

Figure 1. Geographical position of the Zaprešić Brijeg locality, between the villages of Dubrava and Vrhovčak, west of Samobor (after GOOGLE EARTH, December, 2020).

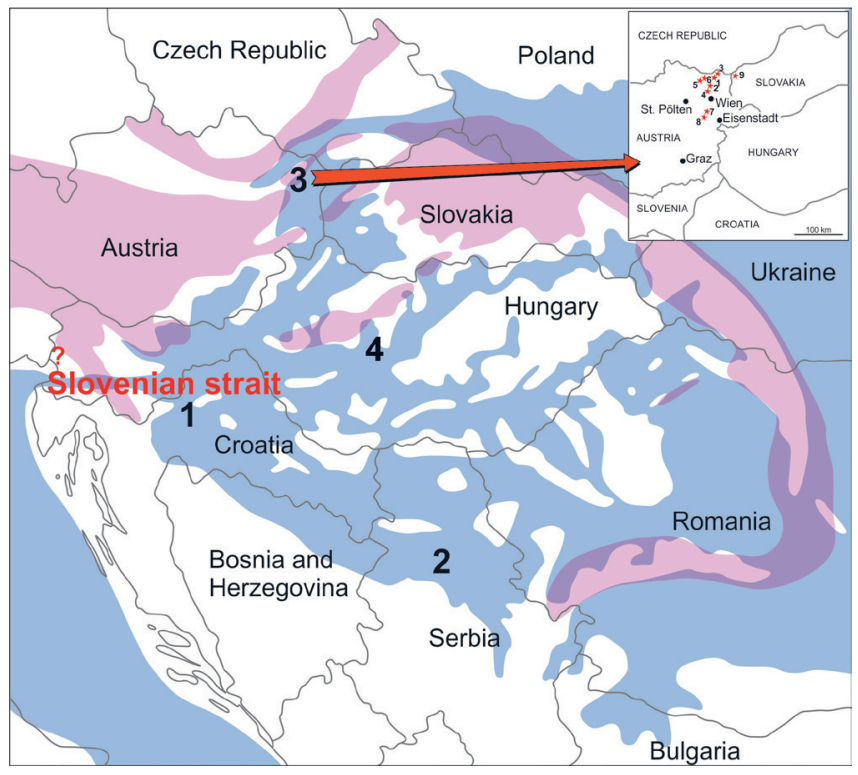

Figure 2. Palaeogeography of the Central Paratethys during the Badenian, 14 Ma (after SANT et al. 2019, Fig. 6A) with marked locations of the study area (1) and comparison localities (2 after GANIĆ et al., 2016, 3 after SAWYER \& ZUSCHIN, 2011, and 4 after GÖRÖG \& SOMODY, 1988). Sketch of localities in Austria and Slovakia in the upper right corner after SAWYER \& ZUSCHIN (2011, Fig. 2) (marked with red asterisks). The blue colour denotes marine areas of normal salinity based on the present-day outcrops; violet denotes regions with no outcrop data for the given time period; ? marks an uncertain area of palaeoconnection through the Slovenian strait (after SANT et al., 2019, Fig. 6A).

belonged to the south-western margin of the Central Paratethys (e.g., RÖGL, 1998; PAVELIĆ, 2001; HARZHAUSER \& PILLER, 2007; KOVÁČ et al., 2007, 2017, 2018; PILLER et al., 2007; PAVELIĆ \& KOVAČIĆ, 2018). Marine connections between the Central Paratethys and the neighbouring marine areas were repeatedly opened and closed during the Miocene, controlling the deposition (RÖGL, 1998; PAVELIĆ, 2001; HARZHAUSER \& PILLER, 2007; KOVÁČ et al., 2007, 2017, 2018; PILLER et al.,
2007; PAVELIĆ \& KOVAČIĆ, 2018). Miocene marine transgressions did not cover the entire Croatian part of the Pannonian Basin System simultaneously, and the basement is therefore unconformably overlain by Neogene deposits of various ages (e.g., PAVELIĆ \& KOVAČIĆ 2018 and references therein).

The presented Zaprešić Brijeg locality is part of the Samoborsko gorje Mt. (Fig. 1). The Neogene basement of the Samoborsko Gorje Mt. is diverse and most commonly composed of Triassic dolomites (GORJANOVIĆ-KRAMBERGER, 1894; ŠUKLJE, 1929), with, at some localities a volcanogenic-sedimentary complex of Cretaceous age, and less often a Palaeogene clastic-carbonate complex (ŠIKIĆ K. et al., 1978, 1979; VRSALJKO et al., 2005 and references therein). The oldest Miocene sediments are Badenian (Langhian) deposits overlying Triassic dolomites. VRSALJKO et al. (2005) describe algal shallow-water limestones as the most common lithotype at the beginning of the transgression. They are overlain by silty marls. BAKRAČ et al. (2010) recognized two Badenian marine transgressive-regressive cycles (TB 2.4 and TB 2.5) in deposits of the neighbouring Vrhovčak section. The Late Badenian marine transgressive-regressive cycle TB 2.5 could be a consequence of a short, but intense marine transgression due to eustatic sea level rise with the opening of the connection between the Central Paratethys and the Indo-Pacific Ocean (VRSALJKO et al., 2005; KOVÁČ et al., 2007; BARTOL et al., 2014).

\section{History of the Zaprešić Brijeg locality investigations}

The geology of the Zaprešić Brijeg locality was first described by GORJANOVIĆ-KRAMBERGER (1894). The basement of the Neogene sediments is composed of Triassic dolomites, and the roof sediments are defined as the "Leithakalk". Below the "Leithakalk", white and light yellow sandstones occur containing a large amount of mollusc shells and other fossils. GORJANOVIĆ-KRAMBERGER $(1894,1896)$ collected and determined the fossil fauna (foraminifera, molluscs, balanids, fish and mammals), and assumed that these Neogene sediments belonged to 
Table 1. Analyzed gastropod families from the CNHM collection with drilling predation data. Abbreviations: $\mathrm{n}=$ number of specimens; $\mathrm{DHS}=$ successfully drilled shells; UDHS = unsuccessfully drilled shells; DF (\%) = drilling frequency; $\mathrm{PE}(\%)=$ prey effectiveness.

\begin{tabular}{|c|c|c|c|c|c|}
\hline \multirow{2}{*}{ FAMILY } & $\mathrm{n}$ & DHS & UDHS & DF (\%) & PE (\%) \\
\hline & 11063 & 633 & 113 & 5.72 & 15.15 \\
\hline Trochidae & 1 & 0 & 0 & 0 & 0 \\
\hline Pisaniidae & 1 & 0 & 0 & 0 & 0 \\
\hline Neritidae & 32 & 0 & 0 & 0 & 0 \\
\hline Melanopsidae & 2 & 0 & 0 & 0 & 0 \\
\hline Pachychilidae & 11 & 0 & 0 & 0 & 0 \\
\hline Cerithiidae & 508 & 65 & 15 & 12.8 & 18.75 \\
\hline Litiopidae & 1 & 0 & 0 & 0 & 0 \\
\hline Scalioidae & 1 & 0 & 0 & 0 & 0 \\
\hline Potamididae & 4459 & 201 & 36 & 4.51 & 15.19 \\
\hline Turritellidae & 1253 & 181 & 28 & 14.45 & 13.4 \\
\hline Rissoidae & 3 & 0 & 0 & 0 & 0 \\
\hline Seguenziidae & 2 & 0 & 0 & 0 & 0 \\
\hline Zebinidae & 1 & 0 & 0 & 0 & 0 \\
\hline Strombidae & 8 & 0 & 0 & 0 & 0 \\
\hline Aporrhaidae & 13 & 1 & 1 & 7.69 & 50 \\
\hline Calyptraeidae & 14 & 0 & 0 & 0 & 0 \\
\hline Naticidae & 90 & 5 & 4 & 5.56 & 44.44 \\
\hline Triviidae & 1 & 0 & 0 & 0 & 0 \\
\hline Eratoidae & 6 & 0 & 0 & 0 & 0 \\
\hline Cassidae & 2 & 0 & 0 & 0 & 0 \\
\hline Charoniidae & 6 & 0 & 0 & 0 & 0 \\
\hline Epitoniidae & 1 & 0 & 0 & 0 & 0 \\
\hline Eulimidae & 1 & 0 & 0 & 0 & 0 \\
\hline Muricidae & 150 & 10 & 2 & 6.67 & 16.67 \\
\hline Tudiclidae & 17 & 1 & 0 & 5.88 & 0 \\
\hline Babyloniidae & 1 & 0 & 0 & 0 & 0 \\
\hline Buccinidae & 2 & 1 & 0 & 50 & 0 \\
\hline Nassariidae & 2428 & 34 & 4 & 1.4 & 10.53 \\
\hline Columbellidae & 11 & 0 & 0 & 0 & 0 \\
\hline Melongenidae & 11 & 1 & 0 & 9.09 & 0 \\
\hline Fasciolariidae & 5 & 0 & 0 & 11.11 & 0 \\
\hline Volutidae & 18 & 0 & 1 & 0 & 100 \\
\hline Mitridae & 3 & 0 & 0 & 0 & 0 \\
\hline Costellariidae & 8 & 0 & 0 & 0 & 0 \\
\hline Olividae & 1 & 0 & 0 & 0 & 0 \\
\hline Ancillaridae & 70 & 2 & 2 & 2.86 & 50 \\
\hline Cancellariidae & 14 & 2 & 0 & 14.29 & 0 \\
\hline Conidae & 12 & 0 & 0 & 0 & 0 \\
\hline Borsoniidae & 18 & 1 & 0 & 5.56 & 0 \\
\hline Drillidae & 13 & 3 & 1 & 23.08 & 25 \\
\hline Clavatulidae & 1813 & 122 & 17 & 6.73 & 12.23 \\
\hline Turridae & 10 & 2 & 1 & 20 & 33.33 \\
\hline Terebridae & 4 & 1 & 1 & 25 & 50 \\
\hline Pyramidellidae & 1 & 0 & 0 & 0 & 0 \\
\hline Acteonidae & 15 & 0 & 0 & 0 & 0 \\
\hline Ringiculidae & 15 & 0 & 0 & 0 & 0 \\
\hline Cylichnidae & 5 & 0 & 0 & 0 & 0 \\
\hline Retusidae & 1 & 0 & 0 & 0 & 0 \\
\hline
\end{tabular}

the „Mediterranean age“ (= Badenian), and compared them with the Grund Formation near Vienna, which he considered to be contemporaneous with the Zaprešić Brijeg sediments based on the fossil fauna and distribution of the gastropod Pereiraea gervaisi (VÉZIAN, 1856) (previously Pereiraia gervaisi) in Croatia, Slovenia and Hungary. The Grund Formation belongs to the middle Miocene - Langhian, that is, in the Central Paratethys chronostratigraphy, the Badenian (e.g., HARZHAUSER et al., 2003, ĆORIĆ et al., 2004). The collected fauna also contains a freshwater species, Vitta picta (FÉRUSSAC, 1823) (old name Neritina picta FÉRUSSAC, 1823), which was probably brought into the marine sediments by river flows. ŚUKLJE (1929) pointed out that the most abundant fossils at Zaprešić Brijeg are gastropods, with the genera Pleurotoma and Cerithium as the most numerous, and confirmed the conclusions of GORJANOVIĆ-KRAMBERGER (1894, 1896). PAVLOVSKY $(1957,1960)$ continued the determinations of the Zaprešić Brijeg gastropods, and assigned the stratigraphic age of the locality to the middle Miocene - Langhian / lower Badenian (in original: „Lower Tortonian“), comparing it to the "Grund" layers. BAJRAKTAREVIĆ (1978), based on the Zaprešić Brijeg foraminifera, concluded that the age of the sediment is middle Miocene - Serravalian / upper Badenian (in the original: „Upper Tortonian“ (Ammonia (= Rotalia) beccarii zone)). Based on the presence of the genera Cerithium, Pirenella and Nassa in the Zaprešić Brijeg assemblage, VRSALJKO (1990) interpreted the palaeoenvironment as shallow marine with sporadic brackish and freshwater areas. MAĐERIĆ (2017) described naticid and muricid drillings from Zaprešić Brijeg within his BSc Thesis, based on gastropods housed at the Faculty of Science, University of Zagreb.

The age of the Zaprešic Brijeg horizons is still not precisely determined. We visited the area several times, in the hope of finding the fossiliferous horizon and conducting further research, but these deposits are no longer available at the surface due to the expansion of settlements, plantations and vineyards. However, due to the presence of the marine gastropod species Pereiraea gervaisi (VÉZIAN, 1856) in the assemblage, the age could be further restricted to the upper part of the middle Badenian or to the upper Badenian (Upper Langhian - Serravallian), close to the NN5 - NN6 nannozone boundary (BARTOL et al., 2014; MIKUŽ \& ŠOSTER, 2014).

\section{MATERIALS AND METHODS}

Analyses of the drilled gastropod shells from Zaprešić Brijeg were made on 11063 specimens from the CNHM collections, inventory numbers 1419-1544, and 10305-10414 (Table 1, Supplement 1). The analyzed fauna was taxonomically categorized into families according to the World Register of Marine Species (WoRMS). Revision of the gastropod fauna in the collection is beyond the scope of this work. This material comprises representatives of marine (44), marine and brackish (2), and brackish (2) families. Four families live as infauna (Naticidae, Turritellidae, Aporrhaidae and Nassariidae), while the other families live as epifauna. Looking at the feeding type of the gastropods, they are categorized into four groups: carnivores, suspension feeders, detritivores and grazers. Two families from freshwater and terrestrial environments were excluded from the analyses due to their non-marine origin.

The first step was to distinguish the drilled from non-drilled gastropod shells. We counted the shells with one and more drillings visible, and based on that, the shells were divided into two groups, drilled and non-drilled gastropod shells. Drilled gastro- 


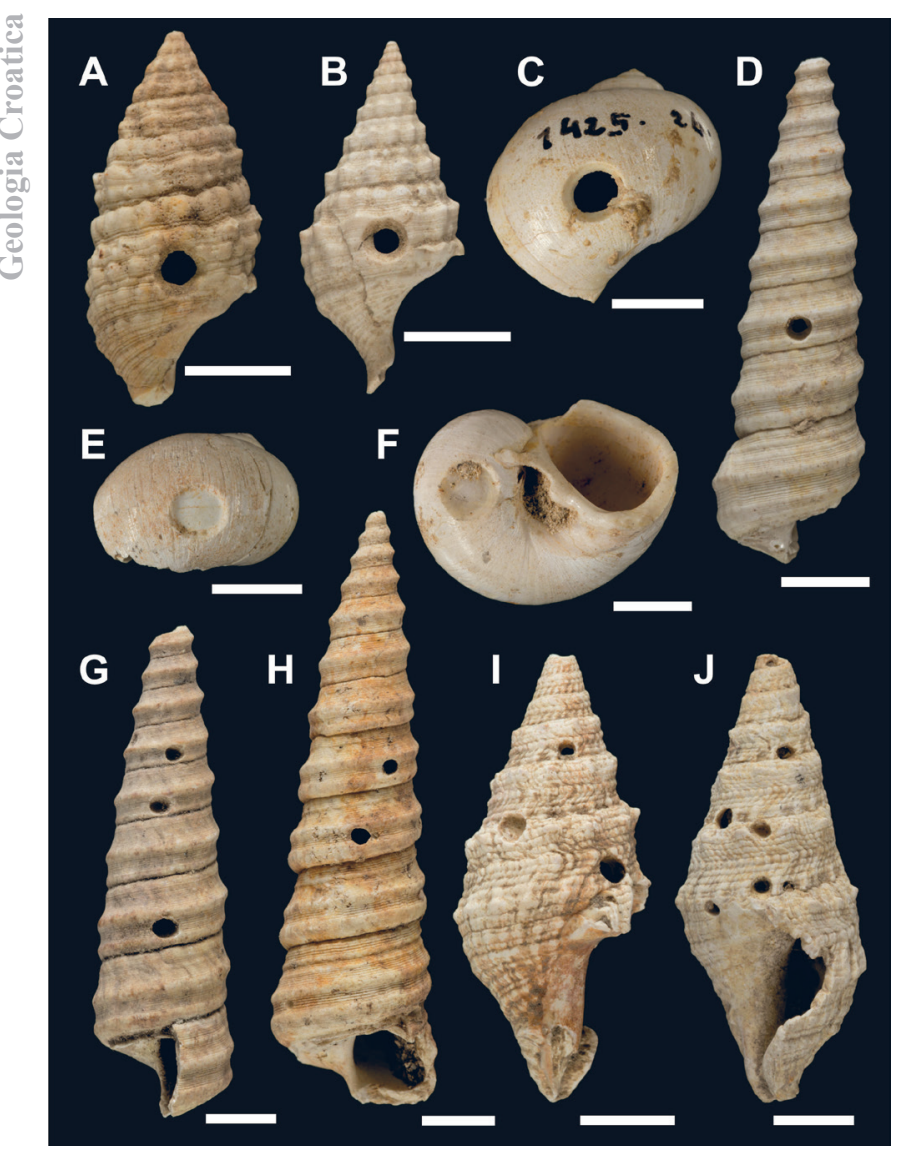

Figure 3. Examples of drilled shells in the analyzed sample. A-D) Successfully drilled shells. E-F) Unsuccessfully drilled shells. G-J) Multiply drilled shells. Scale bar: $5 \mathrm{~mm}$. A, I, J: Inv. No. 10.403. Clavatula (Clavatula) granulatocincta (Münster in Goldfuss, 1840); B: Inv. No. 10.374. Cerithium (Thericium) turonicum (Mayer, 1878); D, G, H: Inv. No. 10.379. Turritella (Eichwaldiella) bicarinata bicarinata Eichwald, 1830; C, E, F: Inv. No. 1425. Natica (Nacca) millepunctata tigrina (Defrance, 1825).

pod shells were further categorized as (a) successfully drilled shells (DHS), (b) unsuccessfully drilled shells (UDHS), and (c) multiply drilled shells (MULT-DHS) (Supplement 1). A successfully drilled gastropod shell has one complete drill hole with one entrance in the shell (Figs. 3A, 3B, 3C, 3D), and an unsuccessfully drilled shell (Figs. 3E, 3F) has one incomplete drill hole with only the outer layer of the shell drilled, and no entrance hole. Multiply drilled shells have more than one successful and/or unsuccessful drill holes (Figs. 3G, 3H, 3I, 3J), showing the traces of predator drillings and parasitic holes on the shell. In this study we focused on the successfully drilled shells (DHS) and unsuccessfully drilled shells (UDHS) showing the predator drillings made by gastropods, not taking into consideration multiply drilled shells and their agents.

Analysis of predation intensity was determined as drilling frequency (DF) (Lower Taxon Frequency (LTF) according to KOWALEWSKI, 2002), which aims to estimate the frequency of interactions for a given taxon of prey (here family) measuring the rate of prey mortality due to the drilling predation (e.g., KELLEY \& HANSEN, 1993; KOWALEWSKI, 2002; SAWYER \& ZUSCHIN, 2011; GANIĆ et al., 2016; PAHARI et al., 2016; SARKAR et al., 2016):

$$
\mathrm{DF}(\mathrm{LTF})=\mathrm{D}_{\mathrm{K}} / \mathrm{N}_{\mathrm{K}},
$$

where $\mathrm{K}$ is a lower taxon target (here family), $\mathrm{D}_{\mathrm{K}}$ is the number of specimens of that taxon that contain one successful predation trace (drill hole) and $\mathrm{N}_{\mathrm{K}}$ is the total number of specimens of that taxon in the sample (after KOWALEWSKI, 2002). In the text we use the term drilling frequency (DF) for the LTF (Lower Taxon Frequency).

The estimate that provides some measure of the predator's failure is called the escalation parameter (KOWALEWSKI, 2002). The relative frequency of failed attacks is often referred to as ,prey effectiveness", which documents traces of unsuccessful attacks (e.g., repair scar or healed drill hole) as described in KOWALESKI (2002):

$$
\mathrm{P}_{\mathrm{E}}=\mathrm{T}_{\mathrm{F}} / \mathrm{T}_{\mathrm{T}}
$$

where $\mathrm{P}_{\mathrm{E}}$ is prey effectiveness computed as $\mathrm{T}_{\mathrm{F}}$, the number of a particular trace fossil of predatory origin that records failed attacks (e.g., the number of incomplete and healed drill holes) divided by $\mathrm{T}_{\mathrm{T}}$, the total number of these trace fossils (e.g., the total number of drill holes) (e.g., KOWALEWSKI, 2002; SAWYER \& ZUSCHIN, 2011; HUTCHINGS \& HERBERT, 2013; GANIĆ et al., 2016; PAHARI et al., 2016; SARKAR et al., 2016).

To indicate a probable predator, we categorized drill holes as made by naticid, muricid or an undeterminable agent, following the descriptions in e.g., HOFFMANN et al., 1974; CARRIKER, 1981; KABAT, 1990; KOWALEWSKI, 2002, 2004. Naticid drillings are parabolic (straight or oblique) and the drill hole is countersunk (outer drill hole diameter is larger than the inner diameter). Muricid drillings are cylindrical, with nearly straight edges.

Abbreviations used in the figures and tables in the following sections are as follows (alphabetically):

$\mathrm{DF}(\%)=$ drilling frequency; $\mathrm{DH}=$ drill hole; $\mathrm{DHS}=$ successfully drilled shells; MULT-DH = multiple drill holes; MULTDHS $=$ multiply drilled shells; $\mathrm{n}=$ number of specimens in the sample; PE $(\%)=$ prey effectiveness; UDHS = unsuccessfully drilled shells.

\section{RESULTS}

Among the 11063 analysed middle Miocene (Badenian) gastropod shells from the Zaprešić Brijeg locality from the CNHM, 1024 shells were drilled (DHS, UDHS and MULT-DHS), among which 746 shells belong to DHS and UDHS, 6.7\% of the studied sample (Supplement 1). The distribution of these categories is shown in Fig. 4. Within the drilled sample ( $9.3 \%$ of the total), $61.8 \%$ exhibit one complete drill hole.

The most numerous families exhibiting drillings in the sample are the Potamididae (4459 specimens), Nassariidae (2428 specimens), Clavatulidae (1813 specimens), Turritellidae (1253 specimens), Cerithiidae (508 specimens), Muricidae (150 speci-

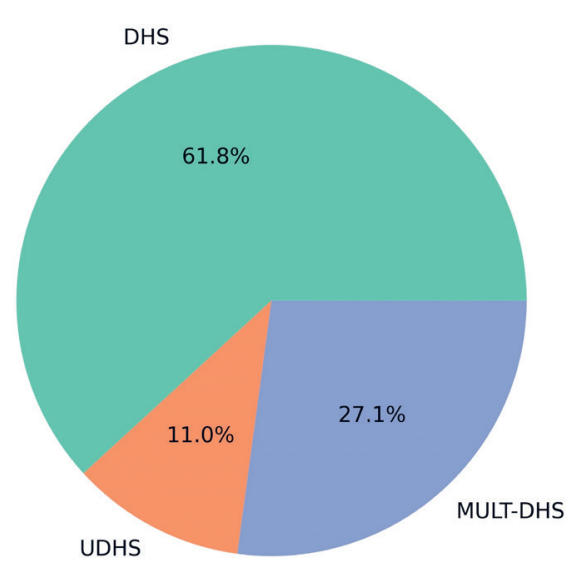

Figure 4. Distribution of the drilled shells categories. 
A

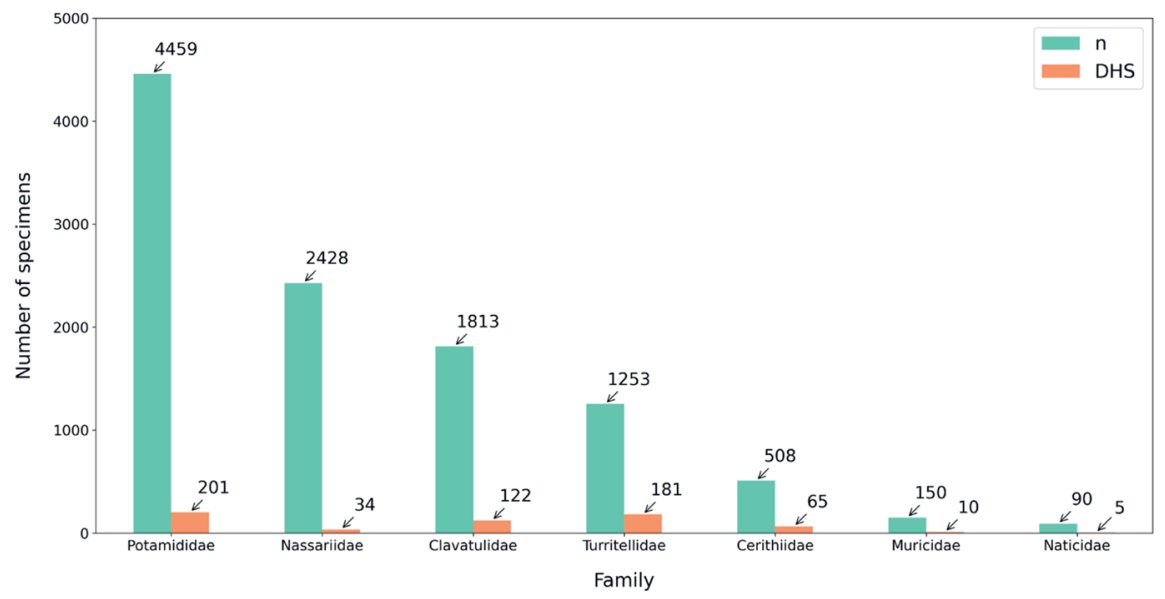

B

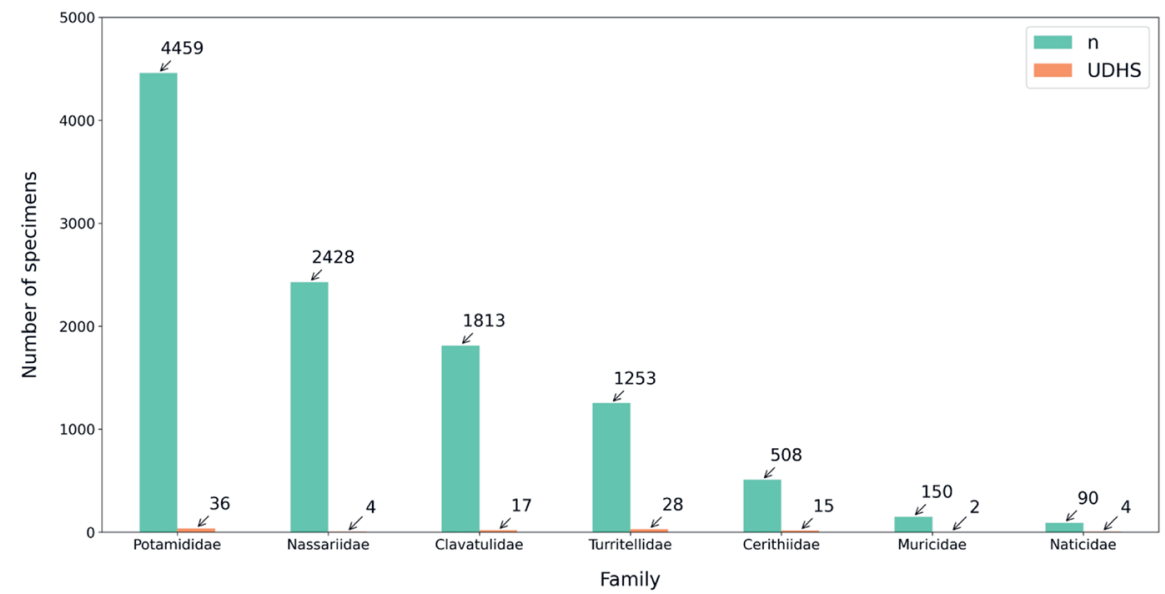

C

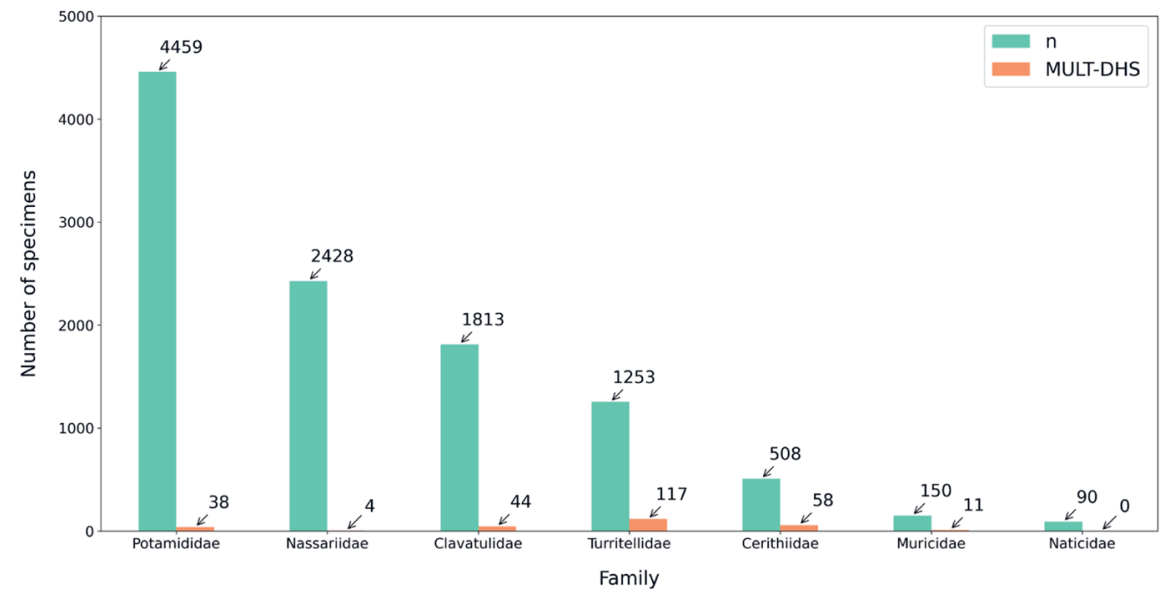

Figure 5. The most numerous gastropod families exhibiting drillings. A) Successfully drilled shells. B) Unsuccessfully drilled shells. C) Multiply drilled shells. Data in Supplements 1 and 2.

mens), and Naticidae (90 specimens) (Fig. 5, Supplement 2). The Potamididae have the highest number of the successfully drilled shells (201), followed by the Turritellidae (181), Clavatulidae (122), Cerithiidae (65), and other families (Fig. 5A, Supplement 2). Potamididae live in the marine and brackish environments as epifauna. Others (Clavatulidae and Cerithiidae) live in marine environments as epifauna, and the Turritellidae are a marine semi-infauna (Supplement 1).

Figure 5B. shows the distribution of the unsuccessfully drilled shells, again with the Potamididae family showing the highest number of unsuccessfully drilled shells (36) as well as the highest number of specimens. The number of unsuccessfully drilled shells is relatively small compared to the successfully drilled shells (Fig. 5A). Other families are represented with less than 30 undrilled shells (Supplements 1 and 2).

The average rate of prey mortality due to the drilling predation (DF) for the whole analyzed gastropod sample is $5.72 \%$ (Table 1, Supplement 1). When we look at the drilling frequencies of the most numerous families in the sample (Supplement 2), DF ranges from $1.4 \%$ (Nassariidae) to $14.45 \%$ (Turritellidae). 

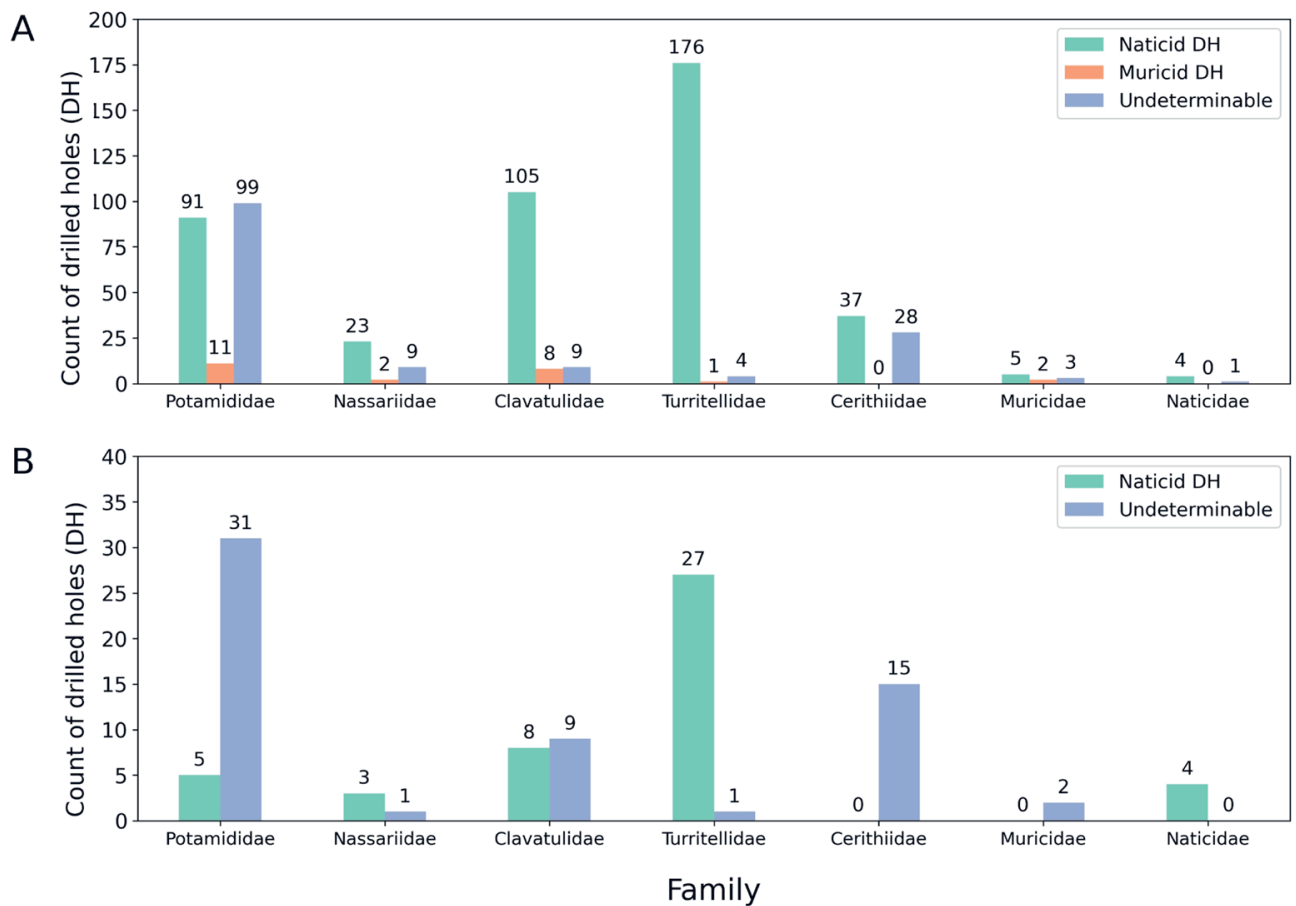

Figure 6. Distribution of potential predators based on the drill hole shape of the most represented families in the sample. A) Successfully drilled shells. B) Unsuccessfully drilled shells. Data shown in Supplements 6 and 7.

Relative frequency of failed attacks (PE) for the analyzed sample is $15.15 \%$ (Table 1, Supplement 1). Looking at the numerously represented families in the sample (Supplement 2), PE ranges from $10.53 \%$ (Nassariidae) to $44.44 \%$ (Naticidae).

Drilling differences between infauna and epifauna in the analyzed sample are shown in Supplements 3 and 4. The average DF of the infauna (5.84\%) is slightly higher than the DF of the epifauna (5.66\%), while the average PE of the infauna (14.34\%) is lower than the PE of the epifauna (15.57\%) indicating that the infauna is less successful at resisting the drilling attack. This result may be affected by the biased preservation of epifaunal gastropod shells, while epifaunal shells are less resistant to various taphonomic processes.

Categorization of the gastropods based on their feeding type and drilling occurence is shown in Supplement 5. Most gastropods represented in the sample are grazers (5029 specimens). The highest DF is observed in the suspension feeders (14.29\%), represented mostly by turritellids, and the lowest among the carnivores $(3.89 \%)$. The highest PE occurs within the detritivores $(50 \%)$, and the lowest within suspension feeders $(13.4 \%)$.
To analyze which prey predators prefer, we looked at the shape of the drill holes and categorized them as naticid drill holes, muricid drill holes and undeterminable, where the attacker is uncertain (Fig. 6, Supplements 6 and 7). Fig. 6A shows the distribution of the categorized drill holes in the sample within the most represented families with successfully drilled gastropod shells. As shown in Fig. 6A, naticid drillings prevail, especially on the shells of the Turritellidae. Examination of the unsuccessfully drilled shells (Fig. 6B), shows that the attacks are mostly undeterminable, and, if they are determinable, they are categorized as naticid drillings, with the majority of the prey belonging to the Turritellidae.

\section{DISCUSSION}

Analyses of drilling predation can offer insight into the palaeoecology of fossil molluscs (e.g., KOWALEWSKI, 2002). Available published papers on drilling predation describing the Central $\mathrm{Pa}-$ ratethys Miocene molluscs as prey and predators, geographically cover the present day area of Poland, Bulgaria, Hungary, Austria, Slovakia and Serbia (Table 2 and references therein).

Table 2. Drilling predation recorded from the Central Paratethys gastropod assemblages.

\begin{tabular}{|c|c|c|c|}
\hline Paper & Studied area & Age or Epoch (in paper) & Predation \\
\hline HOFMANN et al. (1974) & Korytnica clays, Poland & "Lower Tortonian" (= Lower Badenian) & $\begin{array}{l}\text { muricid and naticid predation on molluscs } \\
\text { (gastropods, bivalves, scaphopods) }\end{array}$ \\
\hline KOWALEWSKI (1990) & Korytnica clays, Poland & Middle Miocene & $\begin{array}{l}\text { quantitative paleoecological analysis of predation by } \\
\text { shell drilling gastropods }\end{array}$ \\
\hline ZŁOTNIK (2001) & Korytnica clays, Poland & Middle Miocene & naticid predation on molluscs (bivalves, gastropods) \\
\hline KOJUMDGIEVA (1974) in KABAT (1990) & Bulgaria & Middle Miocene & naticid and muricid predation on gastropods \\
\hline GÖRÖG \& SOMODY (1988) & Hungary & Badenian & predation on gastropods \\
\hline DÁVID $(1993,1999)$ & Wind Brickyard, Hungary & Late Oligocene / Egerian & $\begin{array}{l}\text { naticid predation on molluscs (bivalves, gastropods, } \\
\text { scaphopods) }\end{array}$ \\
\hline SAWYER \& ZUSCHIN (2011) & Austria and Slovakia & Karpatian and Badenian & $\begin{array}{l}\text { drilling predation on molluscs (bivalves, gastropods, } \\
\text { scaphopods) }\end{array}$ \\
\hline ZAGYVAI \& DEMETER (2008) & Waldhof, Austria & Early Sarmatian & gastropods prey-predatory interaction \\
\hline GANIĆ et al. (2016) & Rakovica sand, Serbia & Badenian & molluscs (bivalves, gastropods) drillings \\
\hline
\end{tabular}


Comparison between the Miocene marine deposits of Europe (Boreal and Paratethys provinces - from the present areas of Austria, Slovakia and Hungary) was analyzed by HOFFMEISTER \& KOWALEWSKI (2001), giving the spatial patterns on predation on the Burdigalian and Langhian molluscs. The authors conclude that numerous studies on predator-prey relationship are based on local palaeoecological interpretations and/or long-term temporal trends. Since predation data can significantly vary from one locality or province to another due to the spatial variation in predation, HOFFMEISTER \& KOWALEWSKI (2001) suggest that analyses should concentrate more toward documenting spatial variation in predation analyzing multiple sites (e.g., SAWYER \& ZUSCHIN, 2011). In this presented predation analysis, it was not possible to include more sites into the palaeoecological study (as well as in e.g., GANIĆ et al., 2016). In the published studies on the Central Paratethys Badenian gastropod predation so far, data from Croatia are missing. In the following section we describe and compare drilling predation on gastropods from the Zaprešić Brijeg locality with the available data obtained from the other trace fossil studies on the Badenian gastropods from the Central Paratethys (GÖRÖG \& SOMODY, 1988; SAWYER \& ZUSCHIN, 2011, and GANIĆ et al., 2016).

\subsection{Gastropod Drilling Predation in the Central Paratethys during the Badenian}

Drilling predation studies on the middle Miocene (Badenian) gastropods from the Central Paratethys have been made on the collections from Hungary (GÖRÖG \& SOMODY, 1988) and bulk samples from the Vienna Basin (Austria and Slovakia, in SAWYER \& ZUSCHIN, 2011) and Serbia (GANIĆ et al., 2016). GÖRÖG \& SOMODY (1988) describe drilling and settlement traces on Badenian gastropods from the sand pit at Várpalota in Hungary. The Várpalota fauna (further in the text we refer to it as V-H), with 6620 specimens (after Table 1 in GÖRÖG \& SOMODY, 1988) is dominated by the herbivorous gastropod families Potamididae and Turritellidae. The main predators are the naticids and muricids. SAWYER \& ZUSCHIN (2011) analyze drilling predation on molluscan assemblages from the lower and middle Miocene (upper Burdigalian/Karpatian, Langhian-lower Serravallian/Badenian) localities in Austria and Slovakia (Vienna Basin; further in the text we refer to it as VB). The bulk sample consists of 39234 mollusc shells (bivalves, gastropods, scaphopods and polyplacophorans), and the most numerous are gastropods (22292 specimens, of which 9101 are the Badenian gastropods). The authors consider the muricids and naticids as the most likely predators. Mollusc predation from the southern part of the Central Paratethys is described in GANIĆ et al. (2016), on the middle Miocene (Badenian) bulk sample from the Rakovica stream sands near Belgrade (further in the text we refer to it as RSB-S). Authors analyze 2301 shells of molluscs (gastropods and bivalves; 1617 gastropod specimens) drillings, and conclude that carnivorous gastropods are dominant in the sample and the main predators were muricids and naticids.

In Supplement 8. we show the abundance comparison between Badenian gastropods from the Zaprešić Brijeg locality (further in the text is refered to as ZBL-C), with part of the recorded Badenian gastropods from V-H and RSB-S, based on both published and data presented herein for gastropods present in all three localities. The abundance from VB is not shown because that study includes both Karpatian and Badenian localities, with given abundance for only part of the gastropods represented in the Badenian deposits. The most numerous gastropods in ZBL-C and V-H be- long to the Potamididae, with the most abundant number of specimens belonging to the genera Pirenella and Terebralia (Supplement 8), while in RSB-S the potamidids are not recorded. The Nassariidae and Turritellidae families are also abundant at the ZBL-C and V-H localities, and are present in the RSB-S. Among the turritellids the most numerous is the genus Turritella, and from the Nassariidae, the genus Nassarius is the most abundant at the ZBL-C, Dorsanum at V-H, and Nassa at RSB-S. When we compare the distribution of the gastropod predators, naticids and muricids, naticids prevail at $\mathrm{V}-\mathrm{H}$ and $\mathrm{RSB}-\mathrm{S}$ (genus Natica), while in ZBL-C prevail muricids (genus Ocinebrina). The most likely predators at all the described localities, including the VB, are the Naticidae and Muricidae. It should be noted that when we compare the present fossil fauna, differences could be possible due to the gastropods classification. For example, in some cases one genus belongs to one family in one register, and in another register it is assigned to the other family. The numerical ratio of complete analyzed gastropod samples from the above described Central Paratethys localities is shown in Figure 7.

As presented in SAWYER \& ZUSCHIN (2011, Table 3), mollusc drilling frequency (DF) for the Karpatian (upper Burdigalian) and Badenian (Langhian and lower Serravalian) of the Central Paratethys is $7.5 \%$, which is lower in comparison with the neighbouring Miocene areas of the Boreal province $(24.5 \%)$ and the entire Paratethys (14\%) (HOFFMEISTER \& KOWALEWSKI, 2001). The Badenian gastropods of VB display a DF of $9.2 \%$. The DF of the RSB-S gastropods is a similar value, $9.65 \%$. In contrast, DF in the ZBL-C gastropods is significantly lower: 5.72\% (Table 3). There are no data for the DF and PE for the V-H fauna, only the list and number of damaged specimens (see Table 1 and 2 in GÖRÖG \& SOMODY, 1988).

Results for the PE again differ between the compared areas. The PE of the VB Badenian gastropods at 2.2\% (SAWYER \& ZUSCHIN, 2011, Fig. 6B) is lower than the PE of ZBL-C which equals $15.15 \%$, and the PE of $7.18 \%$ of the RSB-S gastropods (Table 3)

Similarities between the DF and PE of the most drilled gastropod shells between ZBL-C, VB and RSB-S are shown in Table 3. Comparing the drillings of the most represented gastropods from the ZBL-C, with the neighbouring Badenian areas in the Paratethys, the highest DF in the marginal area of the Central Paratethys is in the Turritellidae (14.45\%, present paper, and $17.33 \%$ in RSB-S). Cerithiidae also have a higher DF value in the marginal areas of the Central Paratethys (12.8\% in present paper, and $14.41 \%$ in RSB-S). The predator gastropods, Naticidae and

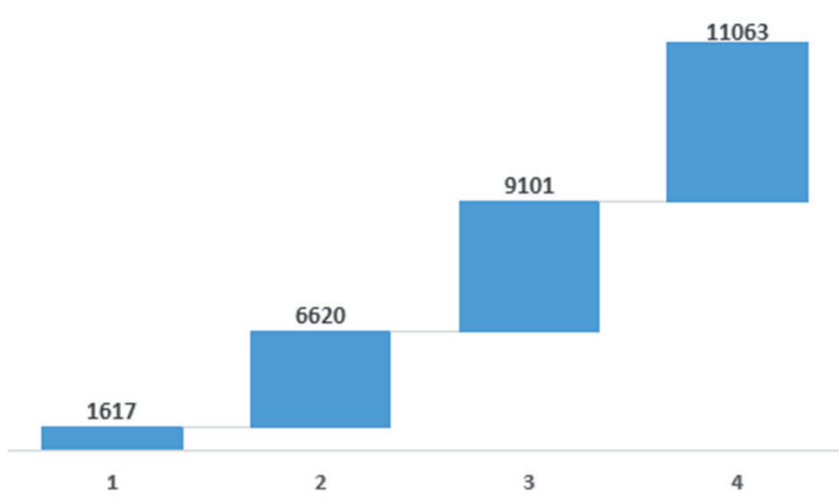

Figure 7. Ratio of gastropod numbers between the compared localities. Legend: 1 = RSB-S after GANIĆ et al. (2016); 2 = V-H after GÖRÖG \& SOMODY (1988); 3 = VB after SAWYER \& ZUSCHIN (2011); 4 = this paper. 
Table 3. Comparison of drilling frequency and prey effectiveness in total and on the most drilled gastropod families between the Zaprešić Brijeg locality (a, this paper), the Central Paratethys (b, after SAWYER \& ZUSCHIN, 2011, Fig. 6), and the Belgrade area at the south-eastern margin of the Central Paratethys ( $c$, after GANIĆ et al., 2016). Symbols: / = no available data; ${ }^{*}=$ Karpatian and Badenian; - = without PE.

\begin{tabular}{lcccccc}
\hline \multirow{2}{*}{ Family } & \multicolumn{3}{c}{$\mathrm{DF}(\%)$} & $\mathrm{PE}(\%)$ \\
\cline { 2 - 7 } & $\mathrm{a}$ & $\mathrm{b}$ & $\mathrm{c}$ & $\mathrm{a}$ & $\mathrm{b}$ & $\mathrm{c}$ \\
\hline Potamididae & 4.51 & 12.5 & $/$ & 15.19 & 0.8 & $/$ \\
\hline Turritellidae & 14.45 & 7.1 & 17.33 & 13.4 & 0 & 7.14 \\
\hline Clavatulidae & 6.73 & $/$ & 0 & 12.23 & $/$ & - \\
\hline Cerithiidae & 12.8 & $7.6^{*}$ & 14.41 & 18.75 & $2.5^{*}$ & 10.53 \\
\hline Nassariidae & 1.4 & 8.5 & 5.03 & 10.53 & 4.4 & 0 \\
\hline Muricidae & 6.67 & $9.6^{*}$ & 0 & 16.67 & $9.1^{*}$ & - \\
\hline Naticidae & 5.56 & 8.3 & 6.12 & 44.44 & 0 & 25 \\
\hline Total (all specimens) & 5.72 & 9.2 & 9.65 & 15.15 & 2.2 & 7.18 \\
\hline
\end{tabular}

Muricidae, have lower DF values in the marginal Central Paratethys areas, than the average of the Central Paratethys (Table 3). The families with the higher DF values in the marginal area have lower values than the Central Paratethys values based on the results from the localities in Austria and Slovakia, and vice versa.

Comparison of the PE shown in Table 3, indicates that the Badenian gastropods from the Central Paratethys marginal areas have higher PE than the average of Central Paratethys. The highest PE in the marginal area have Naticidae $(44.44 \%$ in present study, and $25 \%$ in RSB-S).

As shown in SAWYER \& ZUSCHIN (2011), DFs could fluctuate within similar environments at a single locality. It should be mentioned that comparison on drilling predation between the ZBL-C (this paper), VB and RSB-S is based on uneven gastropod abundances (see Figure 7). The number of specimens within families greatly differ at the mentioned study areas. Also, SAWYER \& ZUSCHIN (2011) made an analyses on multiple sites, and GANIĆ et al. (2016) and this paper only on one locality. Differences in values between naticids and muricids (predator gastropods) could also be the consequence of a smaller amount of predator naticids in marginal areas ( 90 specimens ZBL-C; 49 specimens in RSB-S) than in the Central Paratethys average (403 specimens in VB).

\subsection{Probable Predators of Zaprešić Brijeg Gastropods}

Muricids and naticids are the most likely gastropod predators in the Zaprešic Brijeg. Both groups use a highly specialized accessory boring organ $(\mathrm{ABO})$ which aids the drilling process chemically by secreting an acid which affects prey shell layers by dissolving them and excavates a hole through which the prey tissue is extracted (e.g., CARRIKER, 1981; KABAT, 1990). However, the families differ in their habitat and how they attack (predation style). Muricids live as epifauna and attack mostly epifauna. $\mathrm{Mu}-$ ricoidea in general feed on bivalves, barnacles, gastropods, small crabs, encrusting bryozoans, fish carrion, and may be cannibals (e.g., CARRIKER, 1981 and references therein) as well as herbivores, but the majority of muricids are shell drillers primarily interested in gastropods (e.g., KABAT, 1990). Also, muricids attack in groups, so the multiple muricid drilling could be a consequence of group hunt (e.g., HOFFMANN et al., 1974). On the other hand, naticids live as infauna and attack mostly infaunal organisms. They prey on gastropods, bivalves, scaphopods, ostracods, with infaunal gastropods and bivalves as their primary prey (e.g., KA-
BAT, 1990). However, they can also attack on the surface (e.g., HOFFMAN et al., 1974; PAHARI et al., 2016). Naticids do not attack in groups. As described in KABAT (1990), the sequence of prey capture events by extant naticid includes detection of the prey, evaluation, seizure, covering and immobilization of the prey, wrapping in the dilated foot of the naticid, dragging for some distance and covering into sand for commencement of boring. As naticids enfold the prey with their foot and look for the boring place, multiple naticid drillings on one shell could be the consequence of the prolonged time of boring or the fact that naticids do not recognize if the prey is alive or dead and they drill shells which are already drilled (e.g., HOFFMANN et al., 1974). It is possible that naticids just produce multiple drill holes during a single attack (e.g., KABAT, 1990), or as described in GÖRÖG \& SOMODY (1988) the double borings may have been produced by two predators or by one which needed more space to extract the food.

Our assumption here is that the predator drilling was fatal to the prey, and shells having one successful drill hole can possibly support this, although a possibility remains that the prey could escape the predator (KOWALEWSKI, 1990, 2004). Unsuccessfully drilled shells with regenerated drillings (repair scar on the shell) and/or incomplete drillings can be a sign of an unfinished attack from a predator (e.g., CHATTOPADHYAY \& BAUMILLER, 2007, 2010; HUTCHINGS \& HERBERT 2013).

Other potential drillers, except Muricidae and Naticidae, could be the gastropods Marginellidae, Capulidae, Nassariidae, and Cassidae, as well as cephalopods, who are all capable of drilling holes in the shells (e.g., KABAT, 1990; ZLOTNIK, 2001; KLOMPMAKER et al., 2019). Marginellidae are not present in the analyzed sample, so we can discard them as other potential drillers at the studied site. Capulidae are ectoparasitic symbionts of molluscs and echinoderms, with cylindrical drill holes similar to muricid drilling and leave an attachment scar on the host shell (KABAT, 1990). Capulidae are not present in the analyzed sample either, and an attachment scar in the surrounding area of the drill hole is not recorded, so we can also discard them. Nassariidae (2428 specimens) are mobile scavengers and predators, but in the recent nassariids the drill hole diameter is not larger than $0.25 \mathrm{~mm}$, and drillers are mostly juvenile nassariids (ZLOTNIK, 2001). However, we can exclude nassariids due to the fact that they are mostly herbivores or scavengers, in addition to the fact that the studied drillings do not correspond to nassariid drill hole measurements (e.g., KABAT, 1990; KOWALEWSKI, 1990; ZŁOTNIK, 2001). Cassidae (2 specimens) mostly drill echinoid tests (e.g., KABAT, 1990), and rarely bivalve shells (KABAT, 1990; ZŁOTNIK, 2001), so they are not the potential drillers here. Cephalopods (octopuses) are shell boring predators of molluscs, with drillings of an irregular or oval outline and extremely small inner drill hole diameter (e.g. KABAT, 1990). We have recorded smaller and larger drill hole diameters in the analyzed sample, but the drillings were circular so we dismiss cephalopods as possible predators here.

The highest DF from the Zaprešić Brijeg occurs in the family Turritellidae, with naticid drill holes as the most abundant drillings (Fig. 6A, 6B, Supplements 6 and 7). In the successfully drilled shells there are drill holes that look like muricid drillings, as well as undeterminable drill holes (Fig. 6A). In the unsuccessfully drilled shells, the drillings are recognized as naticid or undeterminable (Fig. 6B). Looking at the analyses of the presented gastropod sample, the other naticid choices of prey were mostly potamidids, clavatulids and cerithiids (Fig. 6A), although these 
three families live as epifauna, and the naticids are characterized as predators of infaunal organisms. However, it was noted that muricids also attacked shallow-burrowing bivalves in more offshore habitats, explained by the hypothesis of atypical feeding behaviour, residual nature of the fossil assemblage, smaller fossilization potential of the epifauna, and misidentification of naticid drillings for muricid ones (KOWALEWSKI, 1990). Most of the drill holes in the unsuccessfully drilled shells belong again to three epifaunal families (potamidids, clavatulids and cerithiids), beside turritellids, and most of the drillings are undeterminable in origin, except the majority of drillings on turritellids (Fig. 6B). As shown in Fig. 6, there are more naticid drillings in the sample than the muricid ones, although the number of naticids in the sample (90) is smaller than the muricids (150). Although muricids attack more epifaunal organisms and gastropods, this sample is characterized by most of the drillings being either of naticid or undeterminable origin. Possible reasons for the prevalence of naticids over muricid drillings are: (1) originally there were more naticids in the sample - due to the taphonomic processes they were not present at the locality because of their fragile shells that are more easily carried away in suspension than the muricid shells; (2) a possible rapid burial event - living as infauna, naticids find more easily their way to the surface than the muricids who are epifauna; and (3) mistaking muricid drillings for the naticids, and vice versa, and not recognizing the undeterminable drillings. Other organisms that can produce naticid- and muricidlike drill holes include nematodes, flatworms, octopods and other gastropods (KOWALEWSKI, 2004). At the neighbouring V-H locality GÖRÖG \& SOMODY (1988) give an analyses of the naticid and muricid borings. Although the Muricidae are less abundant in the sample, their drillings prevail, with most drillings on Potamididae (see Table 2 in GÖRÖG \& SOMODY, 1988). Naticid drillings prevail on the Turritellidae and Nassariidae, which is in accordance with the predators mode of life. Distinguishing naticid from muricid drilling solely on morphological criteria can be difficult because the drilling mechanisms are similar (ZŁOTNIK, 2001). Transitions from naticid- to muricid- type of drilling have been noticed (HOFFMANN et al., 1974), and also, the same species can drill holes in different shapes (KOWALEWSKI, 2004). Therefore the determination of the drill hole shape in our sample should be considered as only a probable indication of predator identity, especially given the great number of drill holes categorized as undeterminable (Fig. 6).

\subsection{Comparison with the Recent Assemblages}

Most of the recent research papers dealing with the origin of drillings in gastropod shells are based on laboratory experiments, and focused mostly on predator behaviour (e.g., CHATTOPADHYAY \& BAUMILLER, 2007; CASEY \& CHATTOPADHYAY, 2008, CHATTOPADHYAY et al., 2014). ZŁOTNIK (2001 and references therein) mentioned that the laboratory enduced behaviour (e.g., by starvation) differs from nassariid drilling behaviour in nature. In the samples collected from the Northern Adriatic Sea, turritellids were the most commonly drilled (SAWYER \& ZUSCHIN, 2010). They were mostly drilled by naticids, but since they live buried directly under the sediment surface, they are more susceptible to both muricid and naticid drillers (SAWYER \& ZUSCHIN, 2010 and references therein), as it is also noted in our sample (Fig. 6, Supplements 6 and 7), and e.g., TULL \& BÖHNING-GAESE (1993).

ALLMON (2011) described the ecology of the Turritellidae, pointing out that recent turritellids are mainly sessile semi-infau- nal suspension feeders living in shallow waters of full-marine salinity and temperatures below $20^{\circ} \mathrm{C}$, but also occur as an active group which can crawl on the surface and thrive at a variety of depths, salinities and temperatures, and with probably changed environmental tolerances through history. As pointed out by ALLMON (2011) turritellid drilled shells indicate that their most frequent drilling predators are naticids, which is in concordance with the fossil data presented here and compared to the other studied samples from the Central Paratethys area.

\section{CONCLUSIONS}

Information retrieved from the drilled gastropod shells provides a closer insight into the biotic interaction in this part of the Pannonian Basin System during the Badenian. The Zaprešić Brijeg collections offer the possibility of understanding such biotic interaction due to the abundance of marine gastropod species and the abundance of the drilled shells.

There are several gastropod families recognized as predators, which attack other molluscs, and the results of the presented data analysis point to the Naticidae and Muricidae as the most probable predators. In the studied sample, epifaunal Potamididae have the highest number of the drilled shells, with the majority of them being successful. Comparing the DF of infauna versus epifauna, it is slightly higher in the case of infauna (5.84\%, and $5.66 \%$, respectively). DF comparison between the feeding type is the highest for the suspension feeders (14.29\%), represented mostly by the turritellids, and is lowest for carnivores (3.89\%). The average rate of the gastropod DF at Zaprešic Brijeg is 5.72\%, which is lower than the Badenian gastropods DF average of $9.2 \%$ for Central Paratethys as given in SAWYER \& ZUSCHIN (2011, Fig. 6A), and gastropods DF of $9.65 \%$ from the south-eastern margin of the Central Paratethys (GANIĆ et al., 2016). Average gastropods $\mathrm{PE}$ of the presented assemblage is $15.15 \%$, which is significantly higher than the PE of $2.2 \%$ in the Central Paratethys (SAWYER \& ZUSCHIN, 2011, Fig. 6B), and PE at the southeastern margin of the Central Paratethys of $7.18 \%$ by GANIĆ et al. (2016).

Comparison of the presented data with previously published data from the neighbouring Paratethys areas shows that the Badenian gastropod families with higher DF in the marginal area of the Central Paratethys have lower DF than the same families in the Central Paratethys. In addition, the Badenian gastropods from marginal areas have higher PE than the average of the Central Paratethys. The highest DF at the Zaprešić Brijeg is recorded in the infaunal suspension feeding Turritellidae, with the most abundant naticid drillings. This is in concordance with their life habitat and known predators from both the fossil and recent data.

\section{ACKNOWLEDGMENTS}

The authors are grateful to the Croatian Science Foundation Project IP-2019-04-7042 (Sedimentary paleobasins, water corridors and biota migrations, PI: Professor Marijan KOVAČIĆ, Faculty of Science, University of Zagreb) for the support in preparing the manuscript, the reviewers for the helpful suggestions and comments which improved the paper, Nives BORČIĆ (Croatian Natural History Museum) for taking the photographs of the gastropod specimens, Robert KOŠĆAL (Faculty of Science, University of Zagreb) and Mr. Renato DREMPETIĆ for the graphics, and Davorka RADOVČIĆ, PhD (Croatian Natural History Museum) for the English language suggestions during the preparation of the MS. 


\section{REFERENCES}

ALLMON, W.D. (2011): Natural history of turritelline gastropods (Cerithioidea: Turritellidae): A status report.- Malacologia, 54/1-2, 159-202.

BAJRAKTAREVIĆ, Z. (1978): Upper Tortonian sediments of Zaprešić Brijeg near Samobor, north Croatia (in Croatian with English summary).- Geološki vjesnik, 30/1, 63-67. http://31.147.204.208/clanci/1978_Bajraktarevic_571.pdf

BAKRAČ, K., HAJEK-TADESSE, V., MIKNIĆ, M., GRIZELJ, A., HEĆIMOVIĆ, I. \& KOVAČIĆ, M. (2010): Evidence for Badenian local sea level changes in the proximal area of the North Croatian Basin.- Geologia Croatica, 63/3, 259-269. doi.org/10.4154/GC.2010.21.

BARTOL, M., MIKUŽ, V. \& HORVAT, A. (2014): Palaeontological evidence of communication between the Central Paratethys and the Mediterranean in the late Badenian/early Serravalian.- Palaeogeography, Palaeoclimatology, Palaeoecology, 394, 144-157. doi.org/10.1016/j.palaeo.2013.12.009.

CARRIKER, M.R. (1981): Shell penetration and feeding by Naticacean and Muricacaean predatory gastropods: a synthesis.- Malacologia, 20/2, 403-422.

CASEY, M.M. \& CHATTOPADHYAY, D. (2008): Clumping behavior as a strategy against drilling predation: Implications for the fossil record.- Journal of Experimental Marine Biology and Ecology, 367, 174-179. doi:10.1016/j.jembe.2008.09.020.

CHATTOPADHYAY, D. \& BAUMILLER, T.K. (2007): Drilling under threat: An experimental assessment of the drilling behavior of Nucella lamellosa in the presence of a predator-- Journal of Experimental Marine Biology and Ecology, 352, 257-266. doi:10.1016/j.jembe.2007.08.001.

CHATTOPADHYAY, D. \& BAUMILLER, T.K. (2010): Effect of durophagy on drilling predation: a case study of Cenozoic molluscs from North America.- Historical Biology, 22/4, 367-379. doi: 10.1080/08912961003600445

CHATTOPADHYAY, D., SARKAR, D., DUTTA, S. \& PRASANJIT, S.R. (2014): What controls cannibalism in drilling gastropods? A case study on Natica tigrina.- Palaeogeography, Palaeoclimatology, Palaeoecology, 410, 126-133. doi. org/10.1016/j.palaeo.2014.05.037.

ĆORIĆ, S., HARZHAUSER, M., HOHENEGGER, J., MANDIC, O., PERVESLER, P., ROETZEL, R., RÖGL, F., SCHOLGER, R., SPEZZAFERRI, S., STINGL, K., ŠVÁBENICKÁ, L., ZORN, I. \& ZUSCHIN, M. (2004): Stratigraphy and correlation of the Grund Formation in the Molasse Basin, Northeastern Austria (Middle Miocene, Lower Badenian).-- Geologica Carpathica, 55/2, 207-215.

DÁVID, Á. (1993): Trace fossils on molluscs from the Molluscan Clay (Late Oligocene, Egerian) - a comparison between two localities (Wind Brickyard, Eger, and Nyárjas Hill, Novaj, NE Hungary).- Scripta Geologica, Special Issue, 2, 75-82.

DÁVID, Á. (1999): Predation by Naticid Gastropods on Late - Oligocene (Egerian) Molluscs Collected from Wind Brickyard, Eger, Hungary.-Malacological Newsletter, 17, 11-19.

GANIĆ, M., RADOVIĆ, P., RUNDIĆ, LJ., BRADIĆ, K. \& KNEŽEVIĆ, S. (2016): Traces of drilling predation in the Upper Badenian (Middle Miocene) molluscs from the Rakovica stream (Belgrade).- Geologia Croatica, 69/2, 205-212. doi: 10.4154/gc.2016.14.

GOOGLE EARTH (2001): earth.google.com/web/

GORJANOVIĆ-KRAMBERGER, D. (1894): Geology of Samoborsko gorje Mt. and Žumberak Mt. (in Croatian).- Rad Yugoslav Academy of Sciences and Arts, 120, $1-82$.

GORJANOVIĆ-KRAMBERGER, D. (1896): Ueber das Vorkommen der Pereiraia Gervaisii Vez. sp. in Croatien.- Verhandlungen der k.k. Geologischen Reichsanstalt, $142-143$.

GÖRÖG, Á. \& SOMODY, Á. (1988): Trace fossils on Badenian (Miocene) gastropods from Várpalota, Hungary.- Annales Univ. Sci. Budapestinensis de Rolando Eötvös nom. sec. Geologica, 28, 121-160.

HARZHAUSER, M., MANDIC, O. \& ZUSCHIN, M. (2003): Changes in Paratethyan marine molluscs at the Early/Middle Miocene transition: diversity, palaeogeography and palaeoclimate.- Acta Geologica Polonica, 53, 4, 323-339.

HARZHAUSER, M. \& PILLER, W.E. (2007): Benchmark data of a changing sea - palaeogeography, palaeobiogeography and events in the Central Paratethys during the Miocene-- Palaeogeography, Palaeoclimatology, Palaeoecology, 253, 8-31. doi.org/10.1016/j.palaeo.2007.03.031.

HOFFMAN, A., PISERA, A. \& RYSZKIEWICZ, M. (1974): Predation by muricid and naticid gastropods on the Lower Tortonian mollusks from the Korytnica clays.Acta Geologica Polonica, 24,/1, 249-260.

HOFFMEISTER, A.P. \& KOWALEWSKI, M. (2001): Spatial and Environmental Variation in the Fossil Record of Drilling Predation: A Case Study from the Miocene of Central Europe.- Palaoios, 16, 566-579. doi.org/10.1669/08831351(2001)016<0566:SAEVIT>2.0.CO;2.
HUTCHINGS, J.A. \& HERBERT, G.S. (2013): No honor among snails: Conspecific competition leads to incomplete drill holes by a naticid gastropod.- Palaeogeography, Palaeoclimatology, Palaeoecology, 379-380, 32-38. doi.org/10.1016/j.palaeo.2013.04.003.

KABAT, A.R. (1990): Predatory ecology of naticid gastropods with a review of shell boring predation.- Malacologia, 32, 1, 155-193.

KELLEY, P.H. \& HANSEN, T.A. (1993): Evolution of the Naticid Gastropod PredatorPrey System: An Evaluation of the Hypothesis of Escalation.- Palaios, 8, 358-375.

KLOMPMAKER, A.A., KELLEY, P.H., CHATTOPADHYAY, D., CLEMENTS, J.C., HUNTLEY, J.W. \& KOWALEWSKI, M. (2019): Predation in the marine fossil record: Studies, data, recognition, environmental factors, and behavior.- EarthScience Reviews, 194, 472-520. doi.org/10.1016/j.earscirev.2019.02.020

KOVÁČ, M., ANDREYEVA-GRIGOROVICH, A., BAJRAKTAREVIĆ, Z., BRZOBOHATÝ, R.,FILIPESCU, S., FODOR, L., HARZHAUSER, M., NAGYMAROSY, A., OSZCZYPKO, N., PAVELIĆ, D., RÖGL, F., SAFTIĆ, B., SLIVA, L. \& STUDENCKA, B. (2007): Badenian evolution of the Central Paratethys Sea: paleogeography, climate and eustatic sea level changes.- Geologica Carpathica, 58/6, 579-606.

KOVÁČ, M., HUDÁČKOVÁ, N., HALÁSOVÁ, E., KOVÁČOVÁ, M., HOLCOVÁ, K., OSZCZYPKO-CLOWES, M., BÁLDI, K., LESS, G., NAGYMAROSY, A., RUMAN, A., KLUČIAR, T. \& JAMRICH, M. (2017): The Central Paratethys palaeoceanography: a water circulation model based on microfossil proxies, climate, and changes of depositional environment.- Acta Geologica Slovaca, 9/2, $75-114$

KOVÁČ, M., HALÁSOVÁ, E., HUDÁČKOVÁ, N., HOLCOVÁ, K., HYŽNÝ, M., JAMRICH, M. \& RUMAN, A. (2018): Towards better correlation of the Central Paratethys regional time scale with the standard geological time scale of the Miocene Epoch.- Geologica Carpathica, 69/3, 283-300. doi: 10.1515/geoca2018-0017

KOWALEWSKI, M. (1990): A hermeneutic analysis of the shell-drilling gastropod predation on mollusks in the Korytnica Clays (Middle Miocene; Holy Cross Mountains, Central Poland).- Acta Geologica Polonica, 40, 3-4, 183-213.

KOWALEWSKI, M. (2002): The fossil record of predation: An overview of analytical methods.- In: KOWALEWSKI, M. \& KELLEY, P.H. (eds.): The fossil record of predation. Paleontological Special Papers, 8, Yale University, New Haven, 3-42.

KOWALEWSKI, M. (2004): Drill holes produced by the predatory gastropod Nucella lamellosa (Muricidae): palaeobiological and ecological implications.- Journal of Molluscan Studies, 70/4, 359-370.

MAĐERIĆ, I. (2017): Odnos predator-plijen u miocenskim bentičkim zajednicama na lokalitetu Zaprešić brijeg kraj Samobora [Predator-prey relationship in the Miocene benthic communities at the Zaprešić Brijeg locality near Samobor - in Croatian].- Unpubl. BSc Thesis, Faculty of Science, University of Zagreb, Zagreb, $15 \mathrm{p}$.

MIKUŽ, V. \& ŠOSTER, A. (2014): Several rare Miocene gastropods from surroundings of Šentjernej in Krka basin, Slovenia.- Folia Biologica et Geologica, 55/1, $51-72$.

PAHARI, A., MONDAL, S., BARDHAN, S., SARKAR, D., SAHA, S. \& BURAGOHAIN, D. (2016): Subaerial naticid gastropod drilling predation by Natica tigrina on the intertidal molluscan community of Chandipur, Eastern Coast of India.- Palaeogeography, Palaeoclimatology, Palaeoecology, 451, 110-123. doi. org/10.1016/j.palaeo.2016.03.020

PAVELIĆ, D. (2001): Tectonostratigraphic model for the North Croatian and North Bosnian sector of the Miocene Pannonian Basin System.- Basin Research, 13, 359-376.

PAVELIĆ, D. \& KOVAČIĆ, M. (2018): Sedimentology and stratigraphy of the Neogene rift-type North Croatian Basin (Pannonian Basin System, Croatia): A review.- Marine and Petroleum Geology, 91, 455-469. doi.org/10.1016/j.marpetgeo.2018.01.026

PAVLOVSKY, M. (1957): Ein Beitrag zur Kenntnis Miozäner Gastropoden von Zaprešić-Brijeg bei Samobor (in Croatian with German summary).- Geološki vjesnik, 10 (1956), 51-56. http://31.147.204.208/clanci/1957_Pavlovsky_81.pdf

PAVLOVSKY, M. (1960): Neue Elemente der Fauna von Zaprešić-Brijeg bei Samobor (in Croatian with German summary).- Geološki vjesnik, XIII (1959), 213-216. http://31.147.204.208/clanci/1960_Pavlovsky_133.pdf

PILLER, W., HARZHAUSER, M. \& MANDIC, O. (2007): Miocene Central Paratethys stratigraphy - current status and future directions.- Stratigraphy, 4, 151-168.

RÖGL, F. (1998): Palaeogeographic considerations for Mediterranean and Paratethys seaways (Oligocene to Miocene).- Annalen des Naturhistorischen Museums in Wien, Serie A für Mineralogie und Petrographie, Geologie und Paläontologie, Anthropologie und Prähistorie Wien, 99 (1997), 279-310.

SANT, K., PALCU, D.V., TURCO, E., DI STEFANO, A., BALDASSINI, N., KOUWENHOVEN, T., KUIPER, K.F. \& KRIJGSMAN, W. (2019): The mid Langhian 
flooding in the eastern Central Paratethys: integrated stratigraphic data from the Transylvanian Basin and SE Carpathian Foredeep.- International Journal of Earth Sciences, 108, 2209-2232. doi.org/10.1007/s00531-019-01757-Z

SARKAR, D., BARDHAN, S., MONDAL, S., DAS, A., PAHARI, A., BURAGOHAIN, D. \& SAHA, S. (2016): Predation on recent terebrid gastropods from the indian subcontinent and a spatiotemporal reappraisal based on a revised global database.Malacologia, 59/2, 271-302. http://dx.doi.org/10.4002/040.059.0207

SAWYER, J.A. \& ZUSCHIN, M. (2010): Intensities of drilling predation of molluscan assemblages along a transect through the northern Gulf of Trieste (Adriatic Sea).Palaeogeography, Palaeoclimatology, Palaeoecology, 285, 152-173. doi:10.1016/j. palaeo.2009.11.007

SAWYER, J.A. \& ZUSCHIN, M. (2011): Drilling predation in mollusks from the Lower and Middle Miocene of the Central Paratethys.- Palaios, 26, 284-297. doi:10.2110/palo.2009.p09-161r

ŠIKIĆ, K.; BASCH, O. \& ŠIMUNIĆ, A. (1978): Osnovna geološka karta SFRJ 1:100000, list Zagreb L33-80 [Basic Geological Map of SFRY 1:100000, Zagreb sheet - in Croatian].- Institut za geološka istraživanja Zagreb (1972), Savezni geološki zavod, Beograd.

ŠIKIĆ, K.; BASCH, O. \& ŠIMUNIĆ, A. (1979): Osnovna geološka kartaSFRJ 1:100000. Tumač za list Zagreb L33-80 [Basic Geological Map of SFRY 1:100000, Geology of the Zagreb sheet - in Croatian]. - Institut za geološka istraživanja Zagreb (1972), Savezni geološki zavod, Beograd, 81 p.
ŠUKLJE, F. (1929): Die Mediterranfauna des Zaprešić Brijeg in der Samoborska gora in Kroatien (in Croatian with German summary).- Bulletin de l'institut geologique de Zagreb, III, 1-52.

TULL, D.S. \& BÖHNING-GAESE, K. (1993): Patterns of drilling predation on gastropods of the family Turritellidae in the Gulf of California.- Paleobiology, 19/4, 476-486.

VRSALJKO, D. (1990): Srednjemiocenski gastropodi Zaprešić-brijega kraj Samobora [The Middle Miocene gastropods from the Zaprešić Brijeg locality near Samobor - in Croatian].- Unpubl. M.S. Thesis, University of Zagreb, Zagreb, 52 p.

VRSALJKO, D., PAVELIĆ, D. \& BAJRAKTAREVIĆ, Z. (2005): Stratigraphy and Palaeogeography of Miocene Deposits from the Marginal Area of Žumberak Mt. and the Samoborsko Gorje Mts. (Northwestern Croatia).- Geologia Croatica, 58/2, 133-150. https://doi.org/10.4154/GC.2005.07

WoRMS Editorial Board (2021). World Register of Marine Species. Available from https://www.marinespecies.org at VLIZ. Accessed 2021-06-26. doi:10.14284/170

ZAGYVAI, Á. \& DEMETER, G. (2001): Tracing prey-predatory interactions in the Early Sarmatian (Mid-Miocene) shelly community from Rollsdorf Formation, Waldhof, Austria based on bioerosional observations.-Acta GGM Debrecina Geology, Geomorphology, Physical Geography Series, 3, 51-60.

ZŁOTNIK, M. (2001): Size-related changes in predatory behaviour of naticid gastropods from the Middle Miocene Korytnica Clays, Poland.- Acta Palaeontologica Polonica, 46/1, 87-97. 